\title{
確率過程を利用した最適化手法によるシステム設計支援*1 System Design Support by Optimization Method Using Stochastic Process
}

\author{
吉田 洋 明*2 $\cdot 山$ 口雄 仁*3.石川芳 男*2 \\ Hiroaki YoshidA, Katsuhito Yamaguchi and Yoshio Ishikawa
}

Key Words : System Design, Optimum Design Methodology, Stochastic Process, Flight Trajectory

\begin{abstract}
We proposed the new optimization method based on stochastic process. The characteristics of this method are to obtain the approximate solution of the optimum solution as an expected value. In numerical calculation, a kind of Monte Carlo method is used to obtain the solution because of stochastic process. Then, it can obtain the probability distribution of the design variable because it is generated in the probability that design variables were in proportion to the evaluation function value. This probability distribution shows the influence of design variables on the evaluation function value. This probability distribution is the information which is very useful for the system design. In this paper, it is shown the proposed method is useful for not only the optimization but also the system design. The flight trajectory optimization problem for the hang-glider is shown as an example of the numerical calculation.
\end{abstract}

記号の説 明

\section{$A:$ 規格化定数}

$A_{1}:$ 主翼アスペクト比, 36.0

$A_{1}^{*}:$ 地面効果を考慮した主翼のアスペクト比

$b_{1}:$ 主翼翼幅, $22.9 \mathrm{~m}$

$C_{\mathrm{D}}^{*}$ : 地面効果を考慮した抗力係数

$C_{\mathrm{D} 0}$ : 有害抗力係数

$C_{\mathrm{Df}}:$ 胴体抗力係数, 0.06

$C_{\mathrm{Di}}^{*}$ : 地面効果を考慮した誘導抗力係数

$C_{\text {DW0 }}$ : 主翼最小抗力係数, 0.011

$C_{\mathrm{D}_{\mathrm{r}} \mathrm{W0}}$ : 水平尾翼最小抗力係数, 0.01

$C_{\mathrm{L}}$ : 揚力係数

$E:$ ハンググライダーの持つ全エネルギー

$e:$ 飛行機効率, 0.85

$g:$ 重力加速度, $9.8 \mathrm{~m} / \mathrm{s}^{2}$

$h:$ 摇らぎの幅を与えるパラメター

$I:$ 評価関数

$m:$ 質量, $95 \mathrm{~kg}$

$n:$ 荷重倍数

$S_{1}:$ 主翼面積, $14.6 \mathrm{~m}^{2}$

$S_{2}:$ 水平尾翼面積, $2.3 \mathrm{~m}^{2}$

$S_{\mathrm{f}}$ : 胴体代表断面積, $0.25 \pi \mathrm{m}^{2}$

$t:$ 時間

$V:$ 速度

$x:$ 水平方向距離

*1 (C) 2007 日本航空宇宙学会

平成 18 年 11 月 6 日原稿受理

$* 2$ 日本大学理工学部

*3 日本大学短期大学部

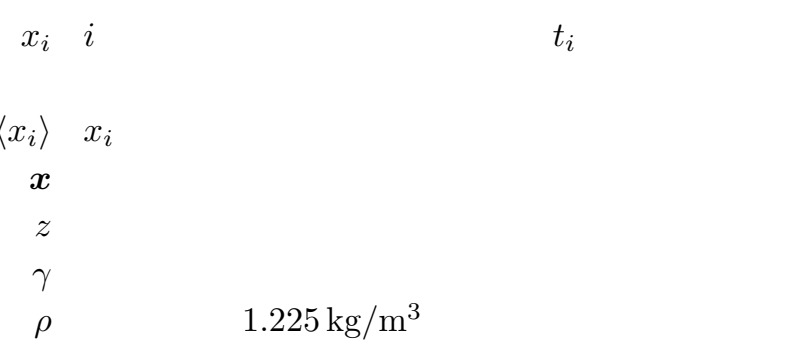

1. はじめに

新しいシステムを設計する場合には，システムが目的を 達成するために必要な構成要素を新たに組み合わせる必要 がある.このとき，構成要素がシステムを成立させるため に必要な能力を備えていることは勿論であるが, コストの 面からは必要以上の能力を持たないことも要求される .こ れは, システムを設計する初期の段階から最適化が必要で あることを意味している．また，システムの性能向上を目 的として構成要素の開発を行う場合には, システムの全体 性能に最も大きい影響を与える構成要素の性能改善を行え ば効率がよい，つまり，システムの性能に対する各構成要 素の感度が分かれば便利である.しかしながら, 設計の初 期段階では構成要素の詳細な仕樣が定まってはおらず, 厳 密な最適解があまり意味を持たないことも多い．また，解 析のために多くの時間やコストをかけることも難しい．し たがって, 手軽に最適解の近似解を得られる手法は, シス テムの設計に非常に有効である.

我々は，確率過程を用いた新しい最適化手法を提案して きた ${ }^{1 \sim 3)}$.これは, 本来確定論的である最適化問題を確率問 題に置き換えることによって, 最適解の近似解を確率平均 である期待值として求める手法である.つまり, 従来の最 
適化手法が解空間内でよりよい解を求めて解の探索を行っ ていたのに対して，本手法はこのような探索を行わずに最 適解の近似解を得ることができる.さらに, 本手法は, 数 值計算を行うために設定すべきパラメターがただ 1 つのみ であるうえ，このパラメターの值は，原理的には，得られ る解に影響を及ぼさない，また，確率過程であることから， モンテカルロ法を利用した数值計算を行いやすいという特 徵を持っている. 光して, 数值計算は期待值を求める計算 であるため, 解の振動や発散の心配がない . 以上のような 特徵から，本手法は最適解の近似解を容易に得ることがで きる．我々は，既に本手法をハンググライダーの機体形状 と飛行経路の統合的最適化問題4,5)に適用し，本手法が一 般的な工学的最適化問題に対して有効であることを示した さらに本手法は, 数値計算上の特徵から, 最適解の近似解 を得られるだけでなく, 設計変数值の発生確率分布を得る ことができるため，これを用いて設計変数の評価値への影 響を知ることができる．したがって，本手法は最適化を行 うためだけでなく，これらの情報を用いてシステムの設計 を効率よく行うことができる .

ここでは, ハンググライダーの最適滑空問題6)を例題と して, 本手法が最適化手法であるだけでなく，工学システ ムの設計を効率よく行うためのツールとして有効であるこ とを示す．

\section{2. 設計変数值の確率分布を利用したシステムの設計支援}

我々の提案する最適化手法を実際の問題に適用し，数值 計算を実行する際には, モンテカルロ法の一種であるメト ロポリス法を利用している .この数値計算においては, 評 価値に比例した確率で解を生成するメカニズムが利用され ている．つまり，最適解の近似解を得る過程で，ある $1 つ$ の設計変数に対して頻繁に発生する值とほとんど発生しな い值があり，これらから設計変数值の発生頻度を得ること ができる.設計変数值の発生頻度は評価值に比例している から，二れは設計変数値の重要度である.すなわち，この 頻繁に発生する設計変数の値つまり発生確率の高い值とは よい評価值を持った解であり，逆に発生頻度の低い設計変 数の值つまり発生確率の低い值とは評価値の悪い解である. したがって，もし，ある設計变数に対する解の相対発生頻度 分布つまり発生確率分布が鋭いピークを持つ場合には，こ の設計変数は評価値に対して高い感度を持っている．逆に， なだらかなピークの確率分布を持つ設計变数は, 評価值に 対する感度が低いため, この設計変数值の変化は評価值つ まりシステムの性能にあまり影響を及ぼさない，以上のよ うに, 本手法は, 最適解を求める数值計算の途中で生成し た解の発生頻度を記録しておくことで, 設計变数值の発生 確率分布を得ることができるため，これにより設計変数值 と評価値の関係を掴むことができる．

このように, 本手法は設計変数值の評価值への影響を発 生確率分布の形で得られるため, システムの最適化にとど まらず，設計を支援するツールとしても使用することがで きる .

\section{3. 確率過程を用いた最適化手法}

ここでは, 量子力学で使われる経路積分7) の概念に基づ き，確率過程を用いた最適化手法の原理を示すとともに，光 れを数值計算によって実現するための数值計算アルゴリズ ムの一例を示す .

3.1 原理 $N$ 個の設計変数を $\boldsymbol{x}=\left\{x_{1}, x_{2}, \cdots, x_{N}\right\}$ ， 評価関数を $I(\boldsymbol{x})$ とする.もし時間に依存する設計变数が あれば，これを時間方向に分割して弚れ光れを独立な設計 変数として扱う. 光して, 次式のような確率分布 $P(\boldsymbol{x})$ を 定義する，

$$
P(\boldsymbol{x})=\frac{1}{A} \exp \left(-\frac{I(\boldsymbol{x})}{h}\right),
$$

ここに，A は確率の総和を 1 とするための規格化定数であ り， $h$ は確率のゆらぎのパラメターである.解の発生確率分 布をこのように定義することにより，評価值の最もよい解 すなわち最適解で確率がピークになり，弚の他の解は光の 周辺に分布することになる．また，ゆらぎのパラメター $h$ は, 確率分布 $P(\boldsymbol{x})$ の幅の大きさを定めるパラメターであ り，本手法で唯一任意に与えるものである.確率分布 $P(\boldsymbol{x})$ は，この $h$ が大きい場合は広く緩やかな分布を，小さい場 合には鋭く急峻な分布となる . ただし , $h$ の大小は , 原理 的には得られる最終的な解に影響を及ぼさない，本手法は， 式 (1) に示したように, 設計変数值 $\boldsymbol{x}$ か評価関数值 $I(\boldsymbol{x})$ に比例した確率分布 $P(\boldsymbol{x})$ に従って発生するメカニズムを 導入することにより，本来確定論的である最適化問題を確 率問題として扱う. 乥して, 式 (1) のような確率分布て解 が存在するとき，期待值はこの確率分布のピークを与える 設計変数值すなわち最適解のよい近似解を与えることが期 待できる. 本手法は，この期待值を求めることで最適解の 近似解を求めるものである.

さて, $i$ 番目の設計変数 $x_{i}$ の期待值 $\left\langle x_{i}\right\rangle$ つまり最適解 の近似解は, 次式のような多重積分によって求められる .

$$
\left\langle x_{i}\right\rangle=\int_{-\infty}^{\infty} \cdots \int_{-\infty}^{\infty} x_{i} \cdot P(\boldsymbol{x}) \mathrm{d} x_{1} \mathrm{~d} x_{2} \cdots \mathrm{d} x_{N},
$$

ここでは，積分区間を $-\infty \sim \infty$ としているが，実際には， 各設計変数の取り得る上下限值に限定することができる.

また，式 (2)に示したように，本手法では最適解か陽に 書き表されていることも他の手法には見られない特徵の 1 つである。

3.2 数值計算アルゴリズム例 ごく限られた例では, 最 適解を式 (1) と式 (2) より，解析的に求めることができる が , 一般的には，式 (2) の積分を解析的に実行することは 困難であるため， これを数值計算によって求めることにな る.しかし, 式 (1)の規格化定数 $A$ を事前に知ることは困 難であるため, 数值積分によって式 (2)の多重積分を直接 実行することも難しい，乥こで，モンテカルロ法の一種で あるメトロポリス法8)を利用して，式 (2)の多重積分を実 


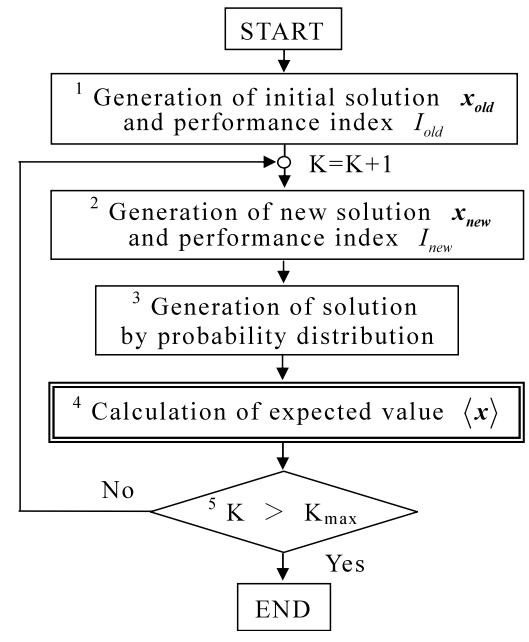

第1図 フローチャート

行する .メトロポリス法によれば, 式 (1)の確率分布に従っ て解を生成することができる. 兴の数値計算アルゴリズム の例を以下に示す．光して，この計算手順のフローチャー 卜を第 1 図に示す . また , 図中の番号は, 以下の計算手順 に付けられたステップ番号に対応している．

Step 1. 初期解の生成. すべての設計変数值を乱数によっ て生成して 1 組の解を作り，二れを初期解 $\boldsymbol{x}_{\mathrm{old}}$ とする. また , このときの評価関数值を $I_{\text {old }}$ とする .

Step 2. 新しい解の生成. 乱数によって新たな解 $\boldsymbol{x}_{\mathrm{new}}$ を 生成し，このときの評価値 $I_{\text {new }}$ を算出する.

Step 3. 確率分布に従う解の選択 .メトロポリス法を用いて， 解の発生確率が式 (1) の確率分布に従うように解 $\boldsymbol{x}_{\mathrm{old}}$ か $\boldsymbol{x}_{\text {new }}$ を選択する．具体的には, $\Delta I=I_{\text {new }}-I_{\text {old }} \leq 0$ (新しい解によって評価值が改善された場合) であれば $\boldsymbol{x}_{\mathrm{new}}$ を採用するが， $\Delta I>0$ (新しい解によって評価值 が改悪された場合) であっても $\exp (-\Delta I / h)$ の確率で $\boldsymbol{x}_{\text {new }}$ を採用する．採用された解を $\boldsymbol{x}_{\text {old }}$ とする .

Step 4. 期待值の計算 .

Step 5. 終了判定. 終了条件を満たしていれば終了し, 満 たしていなけれは乱数による解の生成 (Step 2) に戻る 以上の計算か終了したとき, 得られた期待値は最適解の 近似解となっている.今回, 計算の終了条件は, 単純に解 の生成回数とした .もし, 期待値が十分に収束していない と判断した場合には，さらに続けて計算を行えばよい．

上記のアルゴリズムで期待值を求めるに際しては, 光の 計算過程において, 光の評価値に比例した確率で樣々な解 を生成している (式 (1)) . したがって，これらの解すなわ ち個々の設計变数值の生成回数を保存しておくことにより， 設計变数值の発生頻度分布, すなわち設計变数值の発生確 率分布を得ることができる.

\section{4. ハンググライダーの最適滑空問題}

本手法は最適化問題を解くための手段を提供するもので あるが, 同時に弚の計算過程を通じて設計変数値の発生確 率分布を与えることができるため, システムの設計ツール

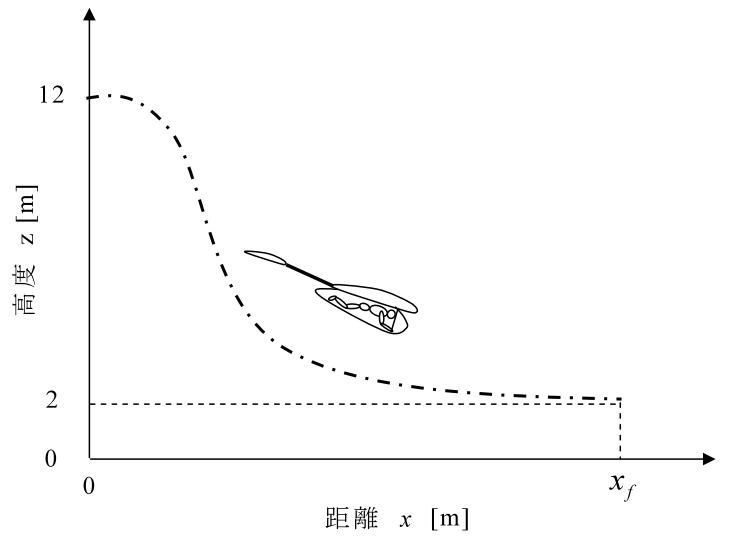

第 2 図 ハンググライダーの滑空問題

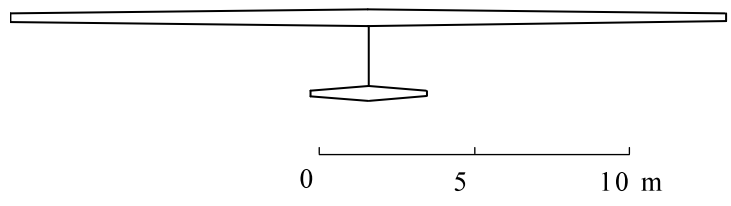

第 3 図 機体平面図

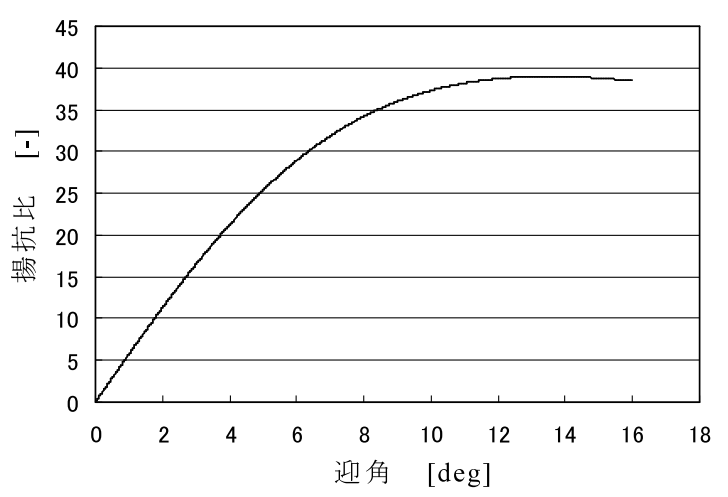

第 4 図 機体の揚抗比

としても利用できる．弚の有効性を示すために，例題とし てハンググライダーの最適滑空問題を採り上げる .

まず，ある 1 つの初期条件の下で, この問題における唯 一の設計変数である迎角の操縦操作 (操縦履歴) の最適化 を行う. 乥して，3.2 節の数值計算過程で生成された各時刻 における迎角の相対発生頻度から迎角の発生確率分布を得 ることで, 各時刻の迎角か評価値に与える影響度を知るこ とができることを示す．次に，いくつかの異なる初期条件 の下で同じ問題を解くことにより，これらの初期条件が最 適解へ及ぼす影響を調べる，乥れにより，システムの最適 設計解の定性的な吟味が可能となることを示す．

4.1 問題設定と運動方程式 今回採り上げるハンググラ イダーの最適滑空問題は，第 2 图に示すように，高度 $12 \mathrm{~m}$ から滑空を開始した機体が高度 $2 \mathrm{~m}$ まで降下する間の飛行 距離 (down range) を最大化する迎角の時間履歴を求める 問題である.使用した機体を第 3 図に示す．乥して，この 機体の揚抗比を第 4 図に示す．ただし，横軸の迎角はゼ口 揚力角 $(-6.8$ 度) を 0 度として表示してある.なお，こ 
第 1 表 各ケースの初期条件と計算回数

\begin{tabular}{|c|c|c|c|}
\hline & \multicolumn{2}{|c|}{ Initial conditions } & \multirow{2}{*}{$\begin{array}{c}\text { Number of } \\
\text { solution }\end{array}$} \\
\hline & $V[\mathrm{~m} / \mathrm{s}]$ & $\gamma[\mathrm{deg}]$ & \\
\hline Case $1(\mathrm{Nml})$ & 5.0 & -3.5 & $9,000,000$ \\
\hline Case $2(\mathrm{Nml} 10)$ & 5.0 & -3.5 & $90,000,000$ \\
\hline Case 3 (V75) & 7.5 & -3.5 & $9,000,000$ \\
\hline Case 4 (G15) & 5.0 & -15.0 & $9,000,000$ \\
\hline Case 5 (V75G15) & 7.5 & -15.0 & $9,000,000$ \\
\hline
\end{tabular}

の機体の主翼翼型には EPPLER5609)，水平尾翼翼型には NACA00129)を用いた。

評価関数の主要な部分は, 飛行距離の逆数であり, 最小 值問題として定式化されている．また，拘束条件として荷 重倍数の最大值を設けており，滑空中にこの制限を超えた 場合には評価值にペナルティを加えている．よって，評価 関数は次式となり，

$$
I=1 / x_{\mathrm{f}}+\sum_{n_{i} \geq n_{\max }} n_{i} / x_{\mathrm{f}} \mathrm{m}^{-1},
$$

ただし， $x_{\mathrm{f}}$ は終端での飛行距離， $n_{i}$ は時間方向に離散化 した時の $t_{i}$ における荷重倍数である.

運動方程式は以下の通りである。

$$
\begin{aligned}
& \dot{V}=-(1 / 2 m) \rho V^{2} S_{1} C_{\mathrm{D}}^{*}-g \sin \gamma, \\
& \dot{\gamma}=(1 / 2 m) \rho V S_{1} C_{\mathrm{L}}-(g / V) \cos \gamma, \\
& \dot{x}=V \cos \gamma, \\
& \dot{z}=V \sin \gamma .
\end{aligned}
$$

ただし，

$$
\begin{aligned}
& C_{\mathrm{D}}^{*}=C_{\mathrm{D} 0}+C_{\mathrm{D} i}^{*}, \\
& C_{\mathrm{D} 0}=C_{\mathrm{DW} 0}+C_{\mathrm{Df}} \cdot \frac{S_{\mathrm{f}}}{S_{1}}+C_{\mathrm{D}_{\mathrm{r}} \mathrm{W} 0} \cdot \frac{S_{2}}{S_{1}}, \\
& C_{\mathrm{D} i}^{*}=C_{\mathrm{L}}{ }^{2} / \pi e A_{1}^{*}, \\
& A_{1}^{*}=\frac{33\left(z / b_{1}\right)^{3 / 2}+1}{33\left(z / b_{1}\right)^{3 / 2}} A_{1} .
\end{aligned}
$$

ここに, $A_{1}^{*}$ は地面効果を考慮した主翼のアスペクト比であ $る^{10)}$.

以下に，すべてのケースについて共通である，初期条件 と拘束条件を示す。

初期条件 : 高度 $z_{0}=12 \mathrm{~m}$,

終端条件: 高度 $z_{\mathrm{f}}=2 \mathrm{~m}$ ，

拘束条件 : 荷重倍数 $n_{\text {max }}=2$.

また ,ケースごとの条件を第 1 表に示す . Case $1(\mathrm{Nml})$ が今回の数値計算における基準であり，数値計算の終了条件 である解の生成回数は 900 万回である. Case 2 ( Nml10) は, Case 1 と同じ初期条件であるが, 解の生成回数のみ 10 倍の 9000 万回としたものである. Case 3 (V75) は Case $1(\mathrm{Nml})$ を基準として初速度を増やしたもの，Case 4 (G15) は初期経路角を隇らしたものであり, 弚して Case 5 (V75G15) は初速度を増やし初期経路角を減らしたもの である .

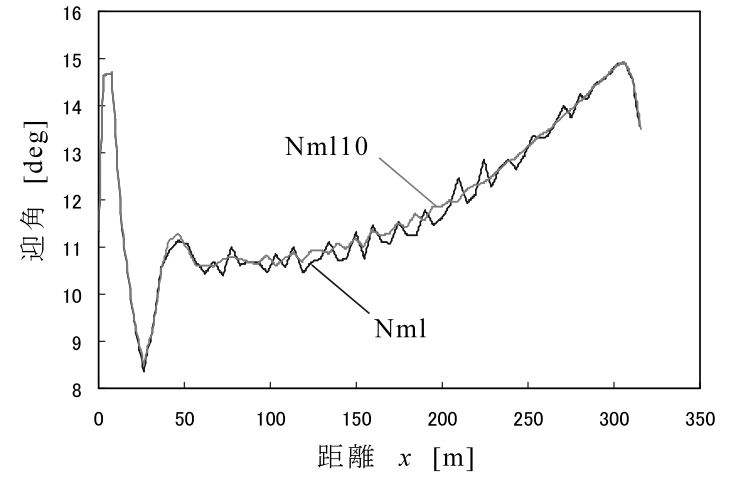

第 5 図 解の生成回数の異なる最適解

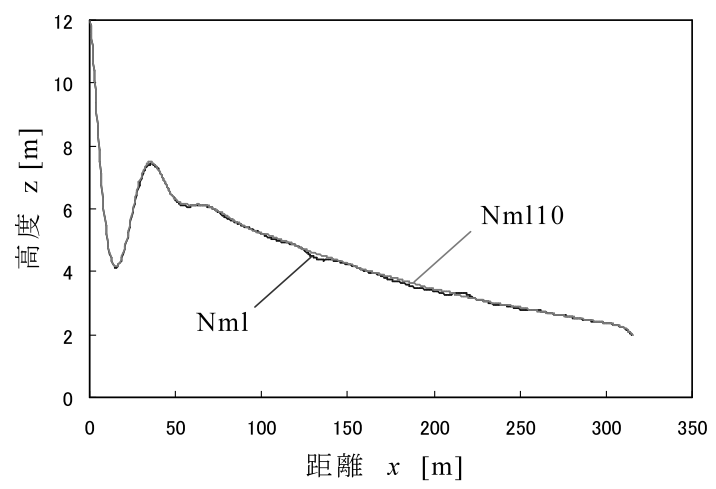

第6 図 解の生成回数の異なる最適解による滑空経路

この問題では, 最適化すべき設計変数は迎角の操縦操作 (操縦履歴) であり，時間の関数である。したがって，迎角 を 0.5 秒ごとに与えて，これらの時系列を設計変数として いる。

4.2 設計変数の評価値への影響 第 5 図に, 本手法に よって得られた Case $1(\mathrm{Nml})$ の最適解 (迎角) と, 生成 回数を光の 10 倍にした Case $2(\mathrm{Nml10})$ の最適解を重ね て示す.横軸は, 滑空距離である.Case 1では得られた迎 角の操作に振動が見られるが, 解の生成回数を产の 10 倍 にした Case 2 では, 滑らかな解が得られている.しかし ながら, 解の生成回数の少ない Case 1 の結果においても, 定性的な解の振る舞いは十分に表されている . また第 6 図 は, Case 1 と Case 2 における滑空距離に対する高度のグ ラフである .これら 2 つのケースにおける滑空経路は, 第 5 図における両者の迎角操作の違いと比べて, 非常によく一 致しており，評価値である滑空距離もほぼ一致しているこ とがわかる . 高い周波数の迎角操作を行っても , 有限の慣 性を有するハンググライダーの運動への影響は小さく，し たがって経路の变化もほとんど無いためである.以上より， この例では解の定性的な振る舞いを調べるのであれば，解 の生成回数は 900 万回で十分であることが分かる .

第 7 図は, 横軸の時間に対して, Case 1 についての最適 解を示したものである.第 8 図が，このとき得られた時間 に対する迎角のヒストグラムつまり迎角の発生確率分布で ある. 平面を成す一方の軸が時間，もう片方の軸は迎角で ある. 高さ方向は, 解の全生成回数に対する各設計変数值 


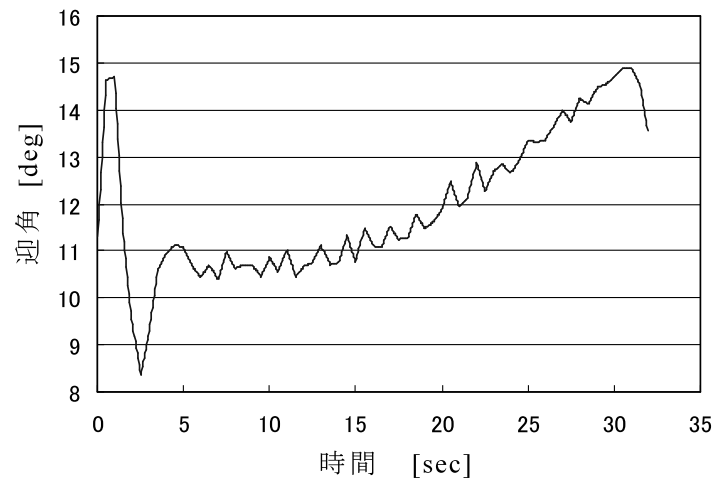

第 7 図 迎角の時間履歴

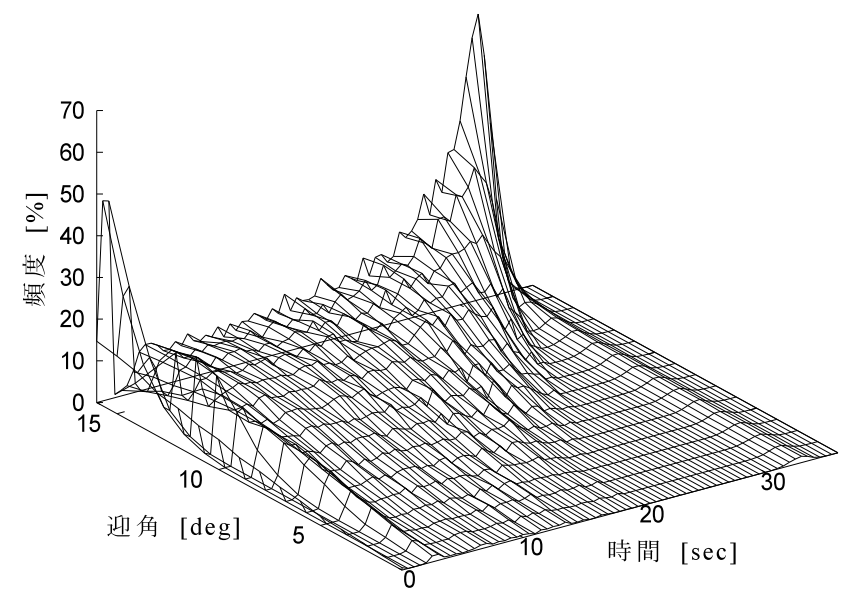

第 8 図 迎角のヒストグラム

の生成回数のパーセンテージである. 各設計変数值の生成 回数とは, 各時刻において迎角があるきざみ幅に入った回 数である.ここでは, 1 度ごとの幅に入った迎角の回数で ある.つまり，高さが高い部分ほど解の全生成回数に対し て产の迎角が出現した回数が多いことを示している. 本数 值計算アルゴリズムは, 式 (1) に示したように評価値に比 例した確率で解の生成を行っているから，このグラフは設 計変数值の発生確率分布を示していると考えてよい. 光し て評価値のよい解ほど頻繁に発生しているから，このパー センテージの高い迎角こ光が，よい評価值を与える操作に 他ならない，また，最適解の近似解は発生したすべての解 の期待値として得られるから，この图の峰に沿った迎角の 時間履歷がほぼ第 7 図に相当する．つまり，この確率分布 のグラフは, 設計変数（ここでは迎角）が評価値へ与える 影響度を示しており，これは, システムの設計に対して非 常に有用な情報となる。

第 7 図の迎角の時間履歴と第 8 図のヒストグラムから， 得られた解の解析を行う. 第 7 図のスタート直後の大きな 迎角操作と終端寸前の操作に対応して, 第 8 图のヒストグ ラムは高いピークを持っている .この高いピークは評価値 に大きく貢献することを意味するから，このピークに相当 する部分の迎角の值は最適解を得るために必須であり，高 い精度の操縦操作が必要とされることを示している．すな
わち, この例においては, 出発直後と終端直前の迎角操作 が, 飛行距離を最大化するために重要である。他方，ピー クの低い中間部分の迎角操作の変化が飛行距離に及ぼす影 響は弚れほど大きくないことが分かる．

ここで再び第 5 図を見直すと, 第 8 図に示したヒストグ ラムで高いピークを持つ滑空開始直後と終端直前では, 解 の生成回数が 900 万回である Case 1 の場合でも迎角の振 動は見られず，解の生成回数が 9000 万回である Case 2 の 場合と非常によく一致している.これは，評価値のよい解 ほど頻繁に発生しているため，この部分では期待值が十分 収束したためである . また, 計算回数 9000 万回の Case 2 の場合でも，滑空距離 50〜200 m では僅かに迎角の振動が 見られる .これは, 第 8 図のヒストグラムの高さが低いこ とからも分かるように, 迎角の変化に対する評価値の変化 が小さいためである．つまり，第 7 図を見るだけでも，得 られた期待値の滑らかさから，滑空開始直後と終端直前の 迎角操作か評価值へ与える影響が大きく，光れ以外の迎角 に振動が見られる部分の操作は小さいことを推定できる .

また, 今回の計算では, 設計変数である迎角の時間履歴 を $0^{\circ} \leq \alpha \leq 16^{\circ}$ の幅でランダムに与えている.これは， 0.5 秒の間に最大 16 度の迎角変化を許すものである . しか し，今回の問題では，このような急激な操作は不要である . したがって，迎角の時間変化に制限を付けることで，現実 的なより滑らかな解をより少ない解の生成回数で求められ る可能性がある.しかしながら，今回は本手法の能力を示 すため，あえて生成する解に対する人為的な操作をすべて 排除している.

このように, 本手法は最適解の近似解と共に設計変数が 評価値に与える影響についての情報も得ることができる . 今回の例題では, 迎角の操縦履歴という時間関数に対する 最適化を行った . 兴の際，分割された時間ステップごとに 乱数で与えられた迎角のひと連なりとして表現された静的 な独立変数の 1 組を, 迎角の時間履歴とみなした .したがつ て, 翼幅のようなもともと静的な設計変数の場合でも，今 回と同樣にヒストグラムを作成することで, 最適化を行う と同時に設計変数の評価值への影響を知ることができる．

4.3 最適解の性質 つぎに, 複数の異なる初期条件の 下で最適化計算を行い，これらの結果から最適解の性質を 調べる。

第 9 図，第 10 図および第 11 図に, Case 1, Case 3〜 Case 5 の異なる 4 つの初期条件に対して最適化を行った結 果を示す. 第 9 図は滑空距離に対する迎角のグラフであり， 第 10 図は，滑空距離に対する高度のグラフである . そとし て，第 11 図は滑空距離に対する荷重倍数のグラフである.

迎角の操縦操作を比較した第 9 図を見ると, 初期速度の 同じケースでは, スタート直後を除いて互いの解の傾向が 非常によく一致している．また，高度を比較した第 10 图で も，スタート直後にいったん高度を下げてから再び高度を 回復した後は, 初期速度の同じケースでは, 互いの滑空経 路がほとんど一致し，滑空距離に対する初期経路角の影響 は見られないことが分かる．これらの計算結果から，最適 


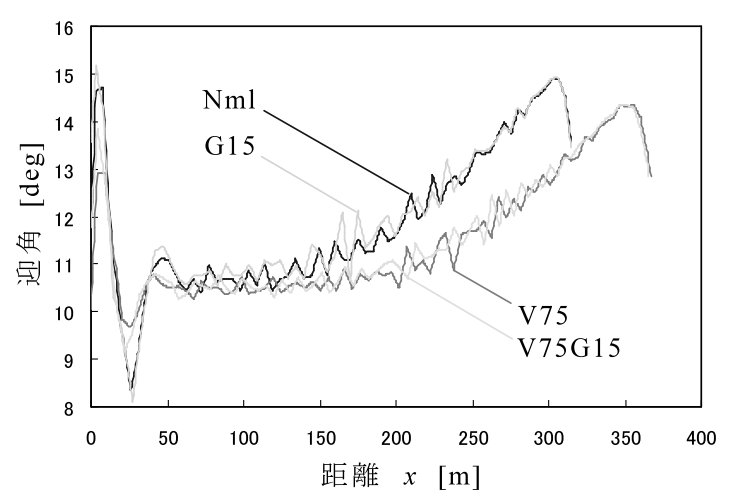

第 9 図 異なる初期条件における最適解の比較

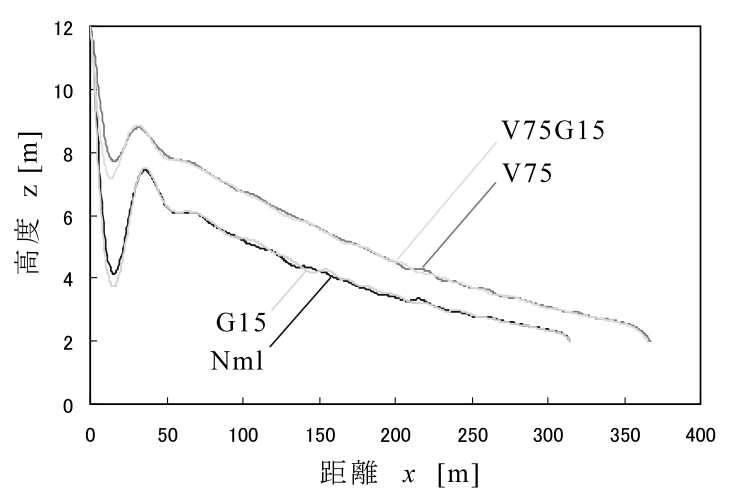

第10図 異なる初期条件における滑空経路の比較

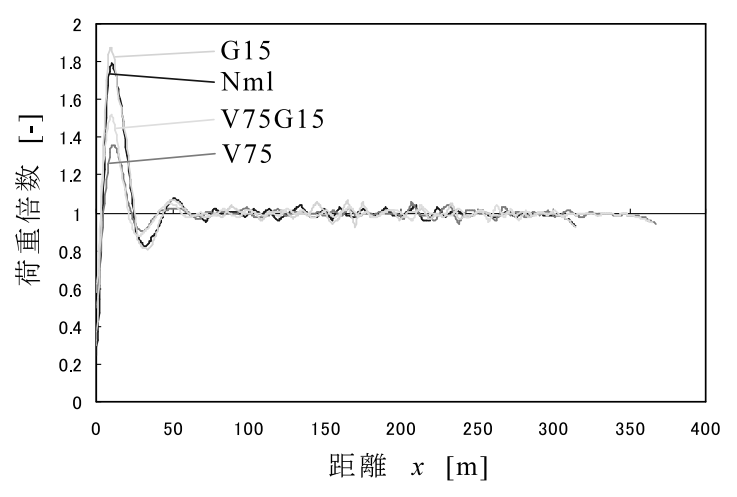

第 11 図 距離に対する荷重倍数の变化

な迎角の操縦操作には, 初期経路角の影響を打ち消す操作 が含まれていると考えられる.として，全飛行区間に亘つ て最適な操縦操作が行われた場合には, 滑空距離は初期速 度のみによって決まることを示している．また，滑空中の 荷重倍数を示した第 11 図を見ると，すべてのケースで荷重 倍数の制限 $(n \leq 2)$ を十分に満たしていることから，今 回の荷重倍数制限は, 最適解に影響を及ぼしていないこと が分かる.

通常，滑空距離を最大とする航空機の飛行は，揚抗比が 最大となる迎角を保つ操縦操作である.第 9 図と第 10 図 を比較すると，いったん高度を下げてから再び高度を回復 した後, 飛行距離 70〜 $150 \mathrm{~m}$ の間はすべてのケースで迎角 がほぼ一定でよく一致している .これは , 第 4 図の揚抗比

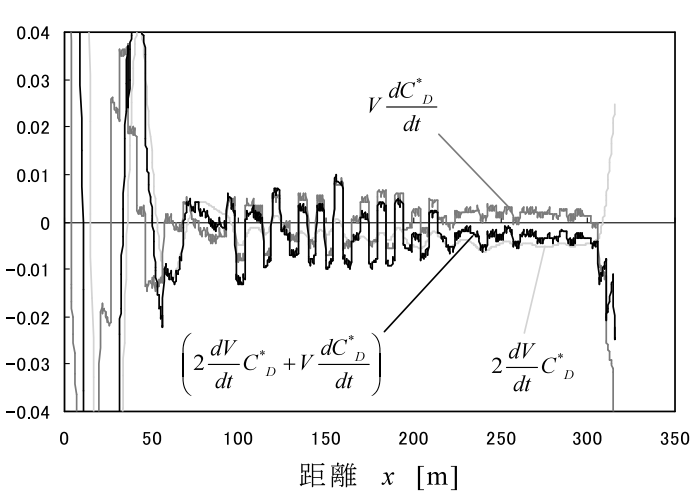

第12 図 式 $(8)$ 括弧内の值の距離に対する変化

のグラフから最大揚抗比での飛行を行っているものと推定 される．ただし，地面効果がある場合には，迎角 10.5 度で は, 高度 $8 \mathrm{~m}$ で約 $5 \%$, 高度 $6 \mathrm{~m}$ で約 $7.4 \%$ 程度の揚抗比 の向上が見られる.しかし光れ以降は最大揚抗比を保つ操 作ではなくなり，長く緩やかな引き起こし操作を行った後， 最後に急激な頭下げを行っている．

この原因を調べるために , ハンググライダーのエネルギー に注目する .ハンググライダーの全エネルギー $E$ は, 次式 のように表すことができる，

$$
E=m g z+\frac{1}{2} m \dot{z}^{2}+\frac{1}{2} m \dot{x}^{2} .
$$

上式を滑空経路 $s$ で微分すると，経路に沿ったエネルギー の変化率は次式のように求められる，

$\frac{\mathrm{d} E}{\mathrm{~d} s}=\frac{\mathrm{d}}{V \mathrm{~d} t}\left(m g z+\frac{1}{2} m \dot{z}^{2}+\frac{1}{2} m \dot{x}^{2}\right)=-\frac{1}{2} \rho V^{2} S_{1} C_{\mathrm{D}}^{*}$.

式 (7) は, 滑空経路に沿ったエネルギーの減少率が抗力に 等しいことを示している．さらに，エネルギーの変化率が 極値を採る条件は次式のようになる，

$$
\frac{\mathrm{d}^{2} E}{\mathrm{~d} s^{2}}=-\frac{1}{2} \rho S_{1}\left(2 \frac{\mathrm{d} V}{\mathrm{~d} t} C_{\mathrm{D}}^{*}+V \frac{\mathrm{d} C_{\mathrm{D}}^{*}}{\mathrm{~d} t}\right)=0 .
$$

これをさらに滑空経路 $s て ゙$ 微分して, $\mathrm{d}^{2} V / \mathrm{d} t^{2}$ と $\mathrm{d}^{2} C_{\mathrm{D}}^{*} / \mathrm{d} t^{2}$ が十分小さいとしてこれを無視すれば，式 (8) を満たす極 值が極小值であることが確かめられる．

第 12 図に, Case 2 における, 飛行距離に関する式 (8) の括弧内の各項と括弧内の全体の值を示す .このグラフか ら，迎角を徐々に増やしてゆく後半の操作に入ると，式 (8) の括弧内の值が 0 に近づいていることが分かる．したがっ て, 高度約 $4 \mathrm{~m}$ 以下ではエネルギーの減少率（すなわち抵 抗）を最小とする操縦操作が行われていると推定できる．

以上のことから , ハンググライダーの滑空距離を最大と する操縦操作とは, まず急激なダイブと引き起こしを伴う 初期経路角の影響を打ち消す操作を行った後，つぎに揚抗 比が最大となる迎角での滑空を行い, 乥して最後に高度約 $4 \mathrm{~m}$ で抵抗を最小とする滑空へと切り替える操縦操作であ ることが推定される . 
今回の各ケースの計算に要した計算時間は , Pentium4 $(3.2 \mathrm{GHz})$ を CPU として持つパーソナルコンピュータで 約 17 時間であった．また，解の生成回数を 10 倍にした場 合，計算時間は約 167 時間であり，計算時間も約 10 倍と なった。

4.4 本手法によって得られた知見 以上のように本最 適化手法を設計ツールとして利用した計算結果から , ハン ググライダーの滑空距離を最大とするための迎角の操縦操 作について，以下のような知見が得られた .

滑空開始直後には, 初期経路角の影響を打ち消すために, 初期経路角に応じた高い精度の迎角操作が要求される. 产 して, 高い高度では揚抗比最大となる迎角を維持する必要 があるが, 滑空開始直後と終端直前に比べると評価值に対 する感度は低い . また, 高度約 $4 \mathrm{~m}$ 以下の低高度ではエネ ルギーの減少率 (抵抗) が最小となるような高い精度の迎 角操作が必要である.すなわち, 滑空開始直後と終端寸前 の迎角操作が, 滑空距離の最大化に大きな影響を及ぼすこ とが分かった.

\section{5. おわりに}

確率過程を利用した最適化手法を用いて，ハンググライ ダーの最適滑空問題の高近似解を得た . 本手法によれば, 最 適滑空を行うための迎角操作が得られるだけでなく，各時 間ごとの迎角の発生確率分布を知ることができる．この迎 角の確率分布は評価值に比例するため, このグラフを利用 すれば最適飛行を実現する上での操縦操作の重要度を知る ことができる. 光の結果, 滑空開始直後と終端直前の操作 が滑空距離の最大化に大きな影響を与えることが示された . 以上のように, 本手法は最適解の近似解と同時に設計変
数が評価值へ与える影響度を解の発生確率分布として知る ことができる．したがって，これを利用して評価值への影 響が大きい設計変数に対して優先的に改善を行うなど , シ ステムの設計を支援するための有用なツールとして本手法 を利用できることを示した .

$$
\text { 参 考 文 献 }
$$

1) 近藤理良, 石川芳男, 山口雄仁, 吉田洋明 : 確率過程を用いた工 学的問題の近似解法, 第 6 回計算工学講演会論文集, 2001, pp. 139-140.

2）吉田洋明, 石川芳男, 山口雄仁, 近藤理良 : 経路積分の概念に基 づた工学的最適化問題における新たな最適化手法, 第 5 回最適 化シンポジウム講演論文集 , 2002, pp. 189-194.

3) 吉田洋明, 今野友和, 山口雄仁, 石川芳男 : 経路積分の概念に基 づく確率過程を利用した新たな最適化手法の提案，計算数理工学 論文集 , 5 (2005), pp. 145-150.

4) Terasaki, M., Kondo, M., Yoshida, H., Yamaguchi, K. and Ishikawa, Y.: Integrated Optimization of Airplane Design and Flight Trajectory by New Optimization Method Using a Stochastic Process, Computational Mechanics WCCM VI in Conjunction with APCOM'04, Tsinghua University Press \& Springer-Verlag, Beijing, 2004, Minisymposia Sessions \#MS053, Paper\#328, pp. 1-9.

5) 吉田洋明, 山口雄仁, 石川芳男: 新たな最適化手法を用いた工学シ ステム設計ツールの提案, 日本航空宇宙学会論文集 , 53 (2005), pp. 398-407.

6) Suzuki, S. and Kawamura, N.: Simultaneous Optimization of Sailplane Design and Its Flight Trajectory, J. Aircraft, 33 (1996), pp. 567-571.

7) Feynman, R. P. and Hibbs, A. R.: Quantum Mechanics and Path Integrals, McGraw-Hill Inc., New York, 1965.

8) 神山真一, 佐藤 明 : モンテカルロ・シミュレーション, 朝倉書 店，東京，1997, pp. 28-66.

9) Eppler, R.: Airfoil Design and Data, Springer-Verlag, Tokyo, 1990, pp. 378-379, 488-489.

10) Hoerner, S. F. and Borst, H. V.: Fluid-Dynamic Lift, Published by Mrs. Liselotte A. Hoerner, 1985. 